\title{
CSF Biomarkers in Patients With COVID-19 and Neurologic Symptoms
}

\section{A Case Series}

Arvid Edén, MD, PhD,* Nelly Kanberg, MD,* Johanna Gostner, PhD, Dietmar Fuchs, PhD, Lars Hagberg, MD, PhD, Lars-Magnus Andersson, MD, PhD, Magnus Lindh, MD, PhD, Richard W. Price, MD, Henrik Zetterberg, MD, PhD, and Magnus Gisslén, MD, PhD

Neurology ${ }^{\circledR}$ 2021;96:e294-e300. doi:10.1212/WNL.0000000000010977

\section{Abstract}

\section{Objective}

To explore whether hospitalized patients with severe acute respiratory syndrome coronavirus 2 (SARS-CoV-2) and neurologic symptoms have evidence of CNS infection, inflammation, and injury using CSF biomarker measurements.

\section{Methods}

We assessed CSF SARS-CoV-2 RNA along with CSF biomarkers of intrathecal inflammation (CSF white blood cell count, neopterin, $\beta_{2}$-microglobulin, and immunoglobulin $\mathrm{G}$ index), blood-brain barrier integrity (albumin ratio), and axonal injury (CSF neurofilament light chain protein [NfL]) in 6 patients with moderate to severe coronavirus disease 2019 (COVID-19) and neurologic symptoms who had undergone a diagnostic lumbar puncture. Neurologic symptoms and signs included features of encephalopathies (4 of 6), suspected meningitis ( 1 of 6 ), and dysgeusia ( 1 of 6 ). SARS-CoV-2 infection was confirmed by real-time PCR analysis of nasopharyngeal swabs.

\section{Results}

SARS-CoV-2 RNA was detected in the plasma of 2 patients (cycle threshold [Ct] value 35.0-37.0) and in CSF at low levels (Ct 37.2, 38.0, 39.0) in 3 patients in 1 but not in a second real-time PCR assay. CSF neopterin (median $43.0 \mathrm{nmol} / \mathrm{L}$ ) and $\beta_{2}$-microglobulin (median 3.1 $\mathrm{mg} / \mathrm{L}$ ) were increased in all. Median immunoglobulin $\mathrm{G}$ index (0.39), albumin ratio (5.35), and CSF white blood cell count $(<3$ cells $/ \mu \mathrm{L})$ were normal in all, while CSF NfL was elevated in 2 patients.

\section{Conclusion}

Our results in patients with COVID-19 and neurologic symptoms suggest an unusual pattern of marked CSF inflammation in which soluble markers were increased but white cell response and other immunologic features typical of CNS viral infections were absent. While our initial hypothesis centered on CNS SARS-CoV-2 invasion, we could not convincingly detect SARSCoV-2 as the underlying driver of CNS inflammation. These features distinguish COVID-19 CSF from other viral CNS infections and raise fundamental questions about the CNS pathobiology of SARS-CoV-2 infection.

\author{
Correspondence \\ Dr. Gisslén \\ magnus.gisslen@infect.gu.se
}

\section{MORE ONLINE}

COVID-19 Resources

For the latest articles, invited commentaries, and blogs from physicians around the world NPub.org/COVID19

\footnotetext{
*These authors contributed equally to this work.

From the Department of Infectious Diseases (A.E., N.K., L.H., L.-M.A., M.L., M.G.), Institute of Biomedicine, Sahlgrenska Academy, University of Gothenburg; Region Västra Götaland (A.E., N.K., L.H., L.-M.A., M.G.), Sahlgrenska University Hospital, Department of Infectious Diseases, Gothenburg, Sweden; Institutes of Medical Biochemistry (J.G.) and Biological Chemistry (D.F.), Medical University of Innsbruck, Biocenter, Austria; Department of Neurology (R.W.P.), University of California San Francisco; Department of Psychiatry and Neurochemistry (H.Z.), Institute of Neuroscience \& Physiology, Sahlgrenska Academy at the University of Gothenburg; Clinical Neurochemistry Laboratory (H.Z.), Sahlgrenska University Hospital, Mölndal, Sweden; Department of Neurodegenerative Disease (H.Z.), UCL Institute of Neurology; and UK Dementia Research Institute at UCL (H.Z.), London.

Go to Neurology.org/N for full disclosures. Funding information and disclosures deemed relevant by the authors, if any, are provided at the end of the article.
} 


\section{Glossary}

BBB = blood-brain barrier; $\beta_{2} \mathbf{M}=\beta_{2}$-microglobulin; COVID-19 = coronavirus disease 2019; $\mathbf{C t}=$ cycle threshold; IgG = immunoglobulin G; LP = lumbar puncture; $\mathbf{N f L}=$ neurofilament light protein; $\mathbf{R d R P}=R N A$-dependent $R N A$ polymerase; SARSCoV-2 = severe acute respiratory syndrome coronavirus 2; WBC = white blood cell.

Neurologic manifestations are common features of coronavirus disease 2019 (COVID-19), but questions remain regarding the underlying mechanisms of CNS pathology. ${ }^{1} \mathrm{We}$ have recently reported neuronal injury and glial activation in patients with COVID-19 using plasma markers of axonal and astrocytic damage. ${ }^{2}$ A variety of CNS disorders, including strokes, seizures, and other encephalopathies, have been reported, particularly in severe COVID-19. ${ }^{3-7}$ In contrast, hyposmia and dysgeusia are relatively common in milder infection, possibly indicating viral invasion of the olfactory bulb. ${ }^{8}$

CSF biomarkers are useful in characterizing CNS responses to infection both by direct detection of invading pathogens and by host inflammatory responses. Indeed, CSF white blood cell (WBC) count is often used as the sine qua non indicator of meningitis or encephalitis. Likewise, soluble inflammatory markers can serve as useful measures of the character and consequences of CNS infections. Neopterin (a marker of cellular activation, including macrophage/microglia and astrocytes) and $\beta_{2}$-microglobulin $\left(\beta_{2} \mathrm{M}\right)$ (a component of the major histocompatibility complex class I molecule) have proved to be robust and frequently altered in neuroinflammatory diseases. ${ }^{9,10}$ Similarly, CNS injury can be sensitively detected with CSF neurofilament light chain protein (NfL), a structural component of myelinated axons. ${ }^{9,11}$ In addition, the immunoglobulin G (IgG) index assesses intrathecal antibody responses, and the ratio of CSF albumin to blood concentration (albumin ratio) provides a measure of blood-brain barrier (BBB) disruption. ${ }^{12}$ Together, these biomarkers aid in characterizing the magnitude, character, and effect of viral CNS infections.

Here, we present an analysis of these well-established CSF biomarkers in 6 patients with COVID-19 and neurologic symptoms.

\section{Methods}

\section{Standard Protocol Approvals, Registrations, and Patient Consents}

This study has been approved by the Swedish Ethical Review Authority (2020-01771). All participants provided informed written consent.

\section{Study Population}

We included patients with confirmed COVID-19 infection and neurologic abnormalities who had undergone a diagnostic lumbar puncture (LP). All patients were admitted to
Sahlgrenska University Hospital in Gothenburg, Sweden, between March 1 and April 4, 2020.

\section{Viral Diagnostics}

Infection with severe acute respiratory syndrome coronavirus 2 (SARS-CoV-2) was confirmed with real-time PCR analysis of nasopharyngeal swab specimens. Additional swab specimens and cell-free CSF and plasma samples were analyzed with the same protocols. Nucleic acid from $200 \mu \mathrm{L}$ nasal swab medium, plasma, or CSF was extracted by a MagNA Pure LC instrument (Roche Diagnostics, Mannheim, Germany) with the Total Nucleic Acid isolation kit. The nucleic acids were eluted in $100 \mu \mathrm{L}$ volume, and $5 \mu \mathrm{L}$ of this was used for realtime PCR. Real-time PCR of a target in the RNA-dependent RNA polymerase (RdRP) region (modified from reference 13) was performed in a QS6 instrument (Applied Biosystems, Foster City, CA) in $20 \mu \mathrm{L}$ reactions containing oligonucleotides and Taqman Fast Virus 1-step Mastermix (Applied Biosystems). The sequence of the primers was as follows: RdRP_Fi, GTCATGTGTGGCGGTTCACT; RdRP_Ri, CAACACTATTAGCATAAGCAGTTGT, and RdRP probe, CAGGTGGAACCTCATCAGGAGATGC. After a reverse transcription step at $46^{\circ} \mathrm{C}$ for 30 minutes followed by 10 minutes of denaturation at $95^{\circ} \mathrm{C}, 45$ cycles of 2 -step PCR was performed $\left(15\right.$ seconds at $95^{\circ} \mathrm{C}, 60$ seconds at $\left.56^{\circ} \mathrm{C}\right) .^{13}$ Plasma and CSF samples with detectable SARS-CoV-2 were reanalyzed from stored specimens using the Xpert-Xpress SARS-CoV-2 test (Cepheid, Sunnyvale, CA) according to the manufacturer's instructions. Cycle threshold $(\mathrm{Ct})$ values were used to estimate sample viral load using formula $(47-\mathrm{Ct}) /$ $3.4=\log _{10}$ copies/sample. Ct values $<37$ were regarded as positive, values $>40$ as negative, and values between 37 and 40 as indeterminant.

\section{Biomarker Analyses}

CSF WBC count was performed using routine methods with a limit of detection of 3 cells $/ \mu \mathrm{L}$. CSF and serum $\beta_{2} \mathrm{M}$ concentrations were measured with the $\mathrm{N}$ Latex $\beta_{2} \mathrm{M}$ kit on the Atellica NEPH 630 System (Siemens Healthcare GmbH, Erlangen, Germany). CSF and serum neopterin concentrations were measured with a commercially available immunoassay (BRAHMS, Berlin, Germany). ${ }^{9}$ CSF NfL was measured with a previously described in-house sandwich ELISA. ${ }^{14}$ Because NfL increases with normal aging, NfL concentrations were age adjusted to the median age (65 years) of the study group. ${ }^{11} \mathrm{IgG}$ and albumin concentrations were measured by immunoturbidimetry on a Cobas instrument (Roche Diagnostics, Penzberg, Germany). IgG index and albumin ratio were calculated as previously described. ${ }^{12}$ 


\section{Data Availability}

Researchers can apply for access to anonymized data from the present study for well-defined research questions that are in line with the overall research agenda for the cohort. Please contact the corresponding author.

\section{Results}

\section{Study Population}

During the study period, a total of 112 patients with COVID19 were admitted to the clinic. Six patients who had undergone a diagnostic LP on clinical indications were identified and included in the study. All had respiratory symptoms with hypoxemia requiring hospitalization. Patient characteristics at baseline are shown in the table, and an overview of disease courses and timing of LP for each patient is shown in figure 1. Two patients were previously healthy; 1 had schizophrenia. Of 3 patients with hypertension, 2 had diabetes mellitus, 1 of whom also had ischemic heart disease. Two patients (patients 2 and 4) required intubation and intensive care; patient 5 had an elevated D-dimer 3 days after LP and was subsequently diagnosed with pulmonary emboli. Neurologic signs and symptoms are summarized in the table. The most common neurologic symptoms were various features of encephalopathy, found in patients 1 through 3 and 6 . CT neuroimaging was performed in 4 patients.

Specifically, patient 1 presented with disorientation and lack of spatial awareness. CT scan showed evidence of small vessel disease and global cortical atrophy. Patient 2 was disoriented to time and place, exhibited poor memory and difficulty with fluent speech, performed poorly on simple tasks such as holding a fork or visiting the restroom independently, complained of extreme fatigue, and later developed multiple seizures. He underwent brain $\mathrm{CT}$ and $\mathrm{CT}$ angiography after the seizures and EEG 2 days later that showed no epileptic activity but generalized background slowing while under deep sedation. The CT was normal while CT angiography showed atherosclerotic changes consonant with the patient's underlying risk profile and comorbid conditions. Patient 3 had cognitive slowing, expressive verbal difficulties, and altered personality according to relatives. He had a normal CT scan apart from discrete white matter changes. Patient 4 presented with somnolence, moderate neck stiffness, and photophobia suggesting meningitis and leading to the LP; a CT scan was normal. Patient 5 had dysgeusia and extreme fatigue and described an altered sense of reality. Patient 6 was disoriented to time, person, and situation at admission; was unable to perform simple tasks; and had severely limited verbal communication. None had clear focal motor or sensory neurologic signs by bedside examination. Due to restrictions imposed at the time to prevent transmission to hospital workers and other patients, no MRI scans or additional EEG examinations were performed.

\section{CSF Viral Detection and Biomarkers}

SARS-CoV-2 RNA was detectable in plasma in patients 1 and 2 (Ct values 37.0 and 35.0) and in CSF of patients 3, 4, and 5 (Ct values 39.0, 38.0, and 37.2, respectively). Due to these low levels of viral detection, all plasma and CSF samples with detectable viral RNA were reanalyzed with the Xpert assay. Both reruns in plasma confirmed SARS-CoV-2 RNA detection, while SARS-CoV-2 RNA was undetectable in all 3 CSF samples.

CSF biomarker analyses are shown in figure 2, A-D. None of the patients had CSF pleocytosis (WBC $\leq 3$ cells $/ \mu \mathrm{L}$ ) (figure $2 \mathrm{~A})$. The albumin ratio reflecting $\mathrm{BBB}$ integrity and $\mathrm{IgG}$ index reflecting intrathecal IgG synthesis were within the normal range in all (figure $2 \mathrm{~B}$ ). The median (range) albumin ratio was

Table Patient Characteristics

\begin{tabular}{|c|c|c|c|c|c|c|c|c|c|}
\hline \multirow[b]{2}{*}{ Patient } & \multirow[b]{2}{*}{ Sex } & \multirow[b]{2}{*}{$\begin{array}{l}\text { Age, } \\
\text { y }\end{array}$} & \multirow[b]{2}{*}{$\begin{array}{l}\text { Comorbid } \\
\text { conditions }\end{array}$} & \multirow[b]{2}{*}{$\begin{array}{l}\text { Neurologic signs and } \\
\text { symptoms }\end{array}$} & \multicolumn{5}{|c|}{ At time of LP } \\
\hline & & & & & $\begin{array}{l}\text { POX, \% } \\
\left(\mathrm{O}_{2} \mathrm{~L} / \mathrm{min}\right)\end{array}$ & $\begin{array}{l}\text { CRP, } \\
\mathrm{mg} / \mathrm{L}\end{array}$ & $\begin{array}{l}\text { B-lymph, } \times 10^{9} \\
\text { cells } / \mathrm{L}\end{array}$ & $\begin{array}{l}\text { Creatinine, } \mu \mathrm{mol} / \\
\mathrm{L}(\mathrm{GFR}, \mathrm{mL} / \mathrm{min} / \\
\left.1.73 \mathrm{~m}^{2}\right)\end{array}$ & $\begin{array}{l}\text { ALT, } \\
\mu k a t / L\end{array}$ \\
\hline 1 & $\mathrm{~F}$ & $80 \mathrm{~s}$ & DM, HT & Encephalopathy & $91(4.5)$ & 160 & 0.8 & $76(55)$ & 0.67 \\
\hline 2 & M & $60 \mathrm{~s}$ & $\begin{array}{l}\text { CHD, DM, HT, } \\
\text { obesity }\end{array}$ & $\begin{array}{l}\text { Encephalopathy, extreme } \\
\text { fatigue, memory loss }\end{array}$ & $90(7)$ & 109 & 0.6 & $71(80)$ & 0.5 \\
\hline 3 & M & $60 \mathrm{~s}$ & None & $\begin{array}{l}\text { Encephalopathy, } \\
\text { personality changes }\end{array}$ & $95(2)$ & 190 & 1.1 & $96(68)$ & 0.5 \\
\hline 4 & M & $60 \mathrm{~s}$ & Schizophrenia & $\begin{array}{l}\text { Moderate neck stiffness, } \\
\text { photophobia, somnolence }\end{array}$ & $95(15)$ & 120 & 1.3 & $242(22)$ & 2.3 \\
\hline 5 & M & $40 \mathrm{~s}$ & None & $\begin{array}{l}\text { Extreme fatigue, } \\
\text { dysgeusia, disorientation }\end{array}$ & $96(2.5)$ & 120 & 0.7 & $78(92)$ & 1.1 \\
\hline 6 & M & $70 \mathrm{~s}$ & $\mathrm{HT}$ & Encephalopathy & $94(1)$ & 110 & 0.7 & $67(79)$ & 2.4 \\
\hline
\end{tabular}

Abbreviations: $\mathrm{ALT}=$ alanine aminotransferase; $\mathrm{B}$-lymph = total blood lymphocyte count; $\mathrm{CHD}=$ coronary heart disease; $\mathrm{CRP}=\mathrm{C}$-reactive protein; $\mathrm{DM}=$ diabetes mellitus; GFR = glomerular filtration rate; $\mathrm{HT}=$ hypertension; $\mathrm{LP}=$ lumbar puncture; $\mathrm{O}_{2}=$ oxygen; $\mathrm{POX}=$ pulse oximeter oxygen saturation. 
5.35 (4.3-9.7) with a reference value of $<10.2$, and the median (range) IgG index was $0.39(0.32-0.43)$ with a reference value of $<0.63$. CSF and serum neopterin concentrations were elevated in all patients with median (range) neopterin concentrations of $43.0(26.7-50.0) \mathrm{nmol} / \mathrm{L}$ in CSF and 41.9 $(38.6-44.4) \mathrm{nmol} / \mathrm{L}$ in serum with upper normal reference values of 5.8 (CSF) and 8.8 (serum) nmol/L. CSF $\beta_{2} \mathrm{M}$ was elevated in 5 of 5 measured CSF samples and in 6 of 6 serum samples. Median (range) $\beta_{2} \mathrm{M}$ concentration was 3.1 $(1.6-7.2) \mathrm{mg} / \mathrm{L}$ in CSF and $3.75(2.8-6.0) \mathrm{mg} / \mathrm{L}$ in serum, with upper normal reference values of $1.8 \mathrm{mg} / \mathrm{L}$ (CSF) and $2.1 \mathrm{mg} / \mathrm{L}$ (serum). CSF neopterin and $\beta_{2} \mathrm{M}$ concentrations were increased in all tested cases (figure 2C). Age-adjusted
CSF NfL was increased in patients 3 and 6 (figure 2D). The median (range) age-adjusted CSF NfL (65 years) was 974 (669-1998) ng/L with an upper normal reference value of $1,577 \mathrm{ng} / \mathrm{L}$.

\section{Discussion}

In this case series study of CSF biomarkers in 6 patients with COVID-19 and neurologic symptoms, we found marked elevations of the 2 soluble inflammatory biomarkers in all and abnormal CSF NfL in 2 patients, while CSF WBC count, albumin ratio, and IgG index were normal in all participants.

Figure 1 Disease Course in the 6 Patients
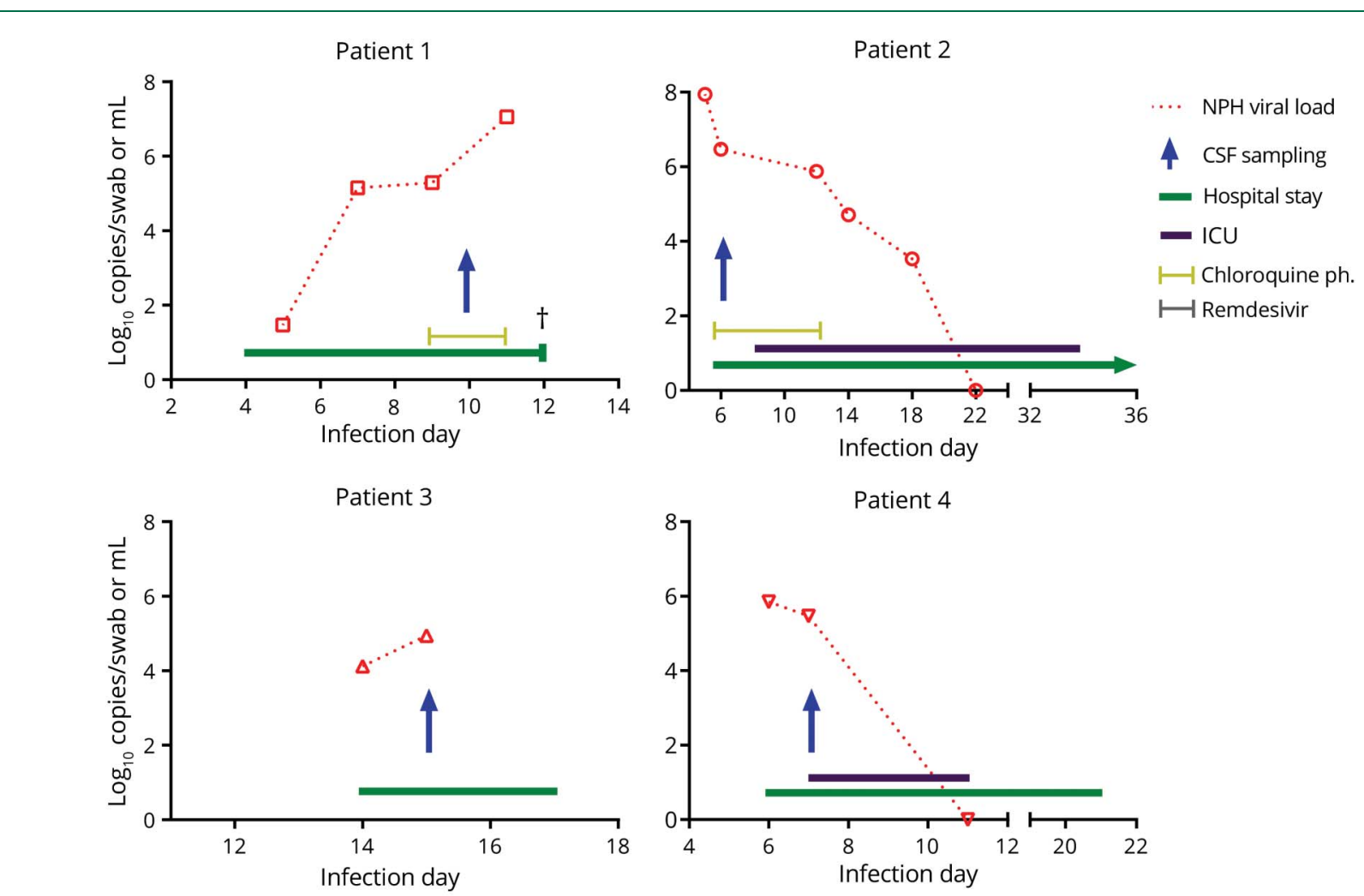

Patient 5
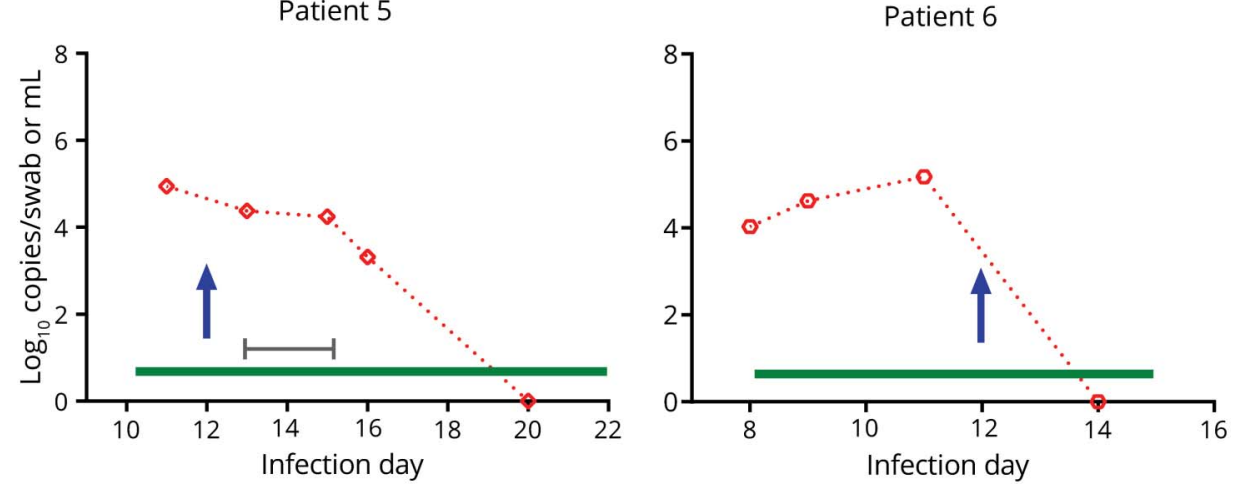

Details of the disease courses in individual patients, including viral load in nasopharyngeal swabs as index. Vertical arrow indicates time of lumbar puncture. Geometric symbols on dashed line are individual as also seen in figure 2. Patient 1 died during the study period. Patient 2 was still admitted at the time of manuscript submission. Patients 3 through 6 were discharged. Patients 1 and 2 were treated with chloroquine phosphate; patient 5 was treated with remdesivir. ICU = intensive care unit; NPH = nasopharynx. 


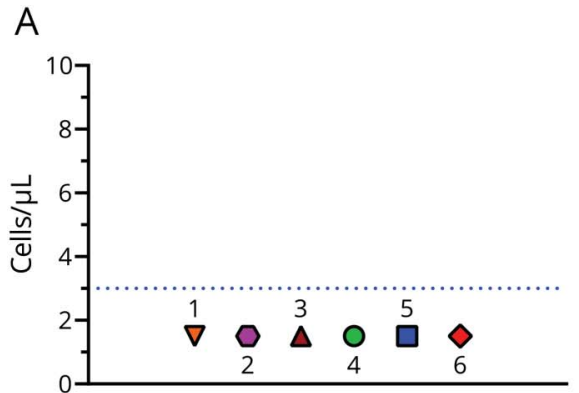

$\mathrm{B}$

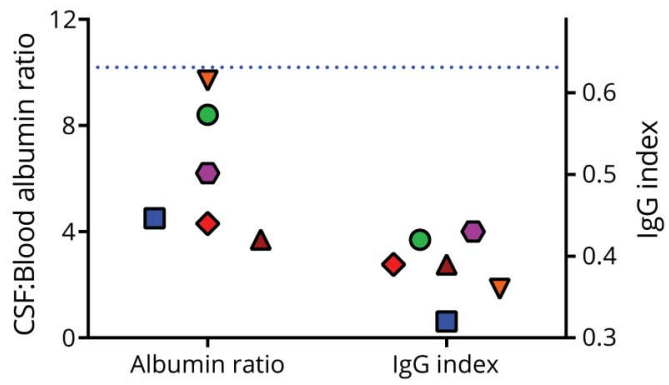

C

D
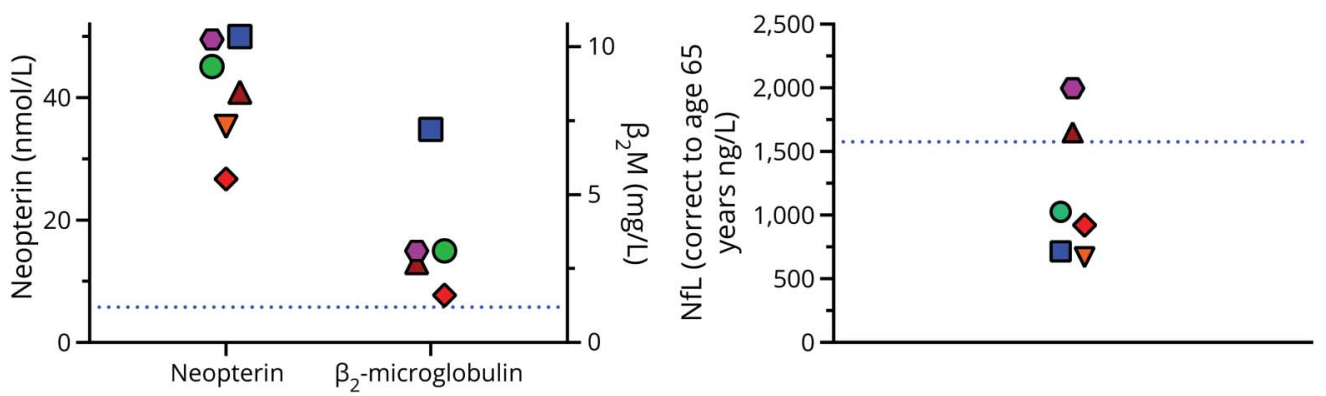

(A) CSF white blood cell was $<3$ cells/ $\mu \mathrm{L}$ in all patients; symbol shape and colors apply to the patient number and are used in all panels. (B) Albumin ratios and immunoglobulin G (IgG) index values were all in the normal range. The median (range) albumin ratio was $5.35(4.3-9.7)$ with a reference value of $<10.2$, and median (range) IgG index was $0.39(0.32-0.43$ ) with a reference value of $<0.63$. (C) CSF neopterin concentrations were elevated in all patients. Median (range) CSF neopterin concentrations were $43.0(26.7-50.0) \mathrm{nmol} / \mathrm{L}$ with an upper normal reference value of $5.8 \mathrm{nmol} / \mathrm{L}$ (CSF). CSF $\beta_{2}$-microglobulin ( $\left.\beta_{2} \mathrm{M}\right)$ was elevated in 5 of 5 measured CSF samples. Median (range) CSF $\beta_{2} \mathrm{M}$ concentration was 3.1 (1.6-7.2) mg/L with an upper normal reference value of $1.8 \mathrm{mg} / \mathrm{L}$. Both normal reference values are indicated by dashed lines. (D) CSF neurofilament light chain protein (NfL) was increased in 2 patients. The median (range) age-adjusted CSF NfL (65 years of age) was 974 (669-1998) ng/L with an upper normal reference value of 1,577 ng/L.

Two patients had low-level plasma viremia, while SARS-CoV2 RNA was detected at indeterminant levels in only 1 of 2 PCR assays in the CSF of 3 patients. These findings outline an unusual pattern in patients with neurologic signs during a viral infection with marked elevation of soluble inflammatory biomarkers in the absence of CSF pleocytosis, BBB disruption, or intrathecal IgG synthesis.

It remains unclear whether SARS-CoV-2 RNA can reach the CNS compartment, although given previous experience in other coronavirus infections, CNS manifestations in COVID19 are not unexpected and provided rationale for this initial study. ${ }^{15,16}$ Animal models of other coronavirus infections also suggest that viral invasion into the CNS can occur. ${ }^{17}$ The taxonomic similarities between SARS-CoV and SARS-CoV-2 have led many to believe that the route of entry to the brain is enabled by the membrane-bound angiotensin-converting enzyme 2. ${ }^{18}$ Angiotensin-converting enzyme 2 has been demonstrated to be expressed in neurons and endothelial and arterial smooth muscle cells in the brain, potentially facilitating SARS-CoV-2 entry across the BBB to subsequently affect the CNS. ${ }^{19}$ However, in these 6 patients with COVID19 and clinically apparent neurologic symptoms, the lack of a cellular CSF response or signs of intrathecal IgG production usually seen in viral meningitis is interesting and implies that the profound CNS immunoactivation reflected by the high CSF neopterin and $\beta_{2} \mathrm{M}$ levels was not driven by direct neuroinvasion of SARS-CoV-2. CSF viral RNA detection has been challenging and has so far been described in 2 singular case reports. $^{20,21}$ This discrepancy between the lack of CSF viral detection and consistent neurologic abnormalities in different stages of COVID-19 infection suggests an alternative pathophysiology in which the intense systemic inflammatory response induced by SARS-CoV-2 infection may be a driving factor. Neuropathogenesis in COVID-19 is likely multifactorial; hypoxemia, hypercoagulability, and systemic inflammation may all contribute to specific stroke syndromes and to the more general or diffuse encephalopathies seen in a majority of our included patients. Underlying comorbid conditions seen in 3 of 6 patients may also play a role in the severity of SARS-CoV-2 infection. The metabolic syndrome has been shown to promote a proinflammatory phenotype in macrophages and other immune cells, which may contribute to the hyperinflammatory response seen in individuals with such underlying conditions and COVID-19 infection ${ }^{22}$ and may increase the risk of vascular complications.

The pathophysiologic bases of the markedly elevated CSF concentrations of the immune activation indicators neopterin and $\beta_{2} \mathrm{M}$ remain uncertain. Although the elevated CSF 
neopterin and $\beta_{2} \mathrm{M}$ suggest CNS monocytic activation, their dissociation from viral detection, pleocytosis, or BBB disruption suggests mechanisms other than direct viral invasion and CNS infection. Because this was a common finding across all 6 patients, it may be a hallmark of more severe SARS-CoV-2 infection and provide a clue to the neurobiology of CNS disturbance and the "indirect" effects of systemic infection and immune activation on the CNS. Further studies across a broader spectrum of infection are needed to explore this further.

CSF NfL was elevated in 2 individuals, indicating axonal injury. We suspect that this may have been caused by an episode of hypoxia or other event but cannot clearly trace the cause. If more directly caused by viral infection or by vigorous CNS inflammation, this cannot be clearly defined in this small dataset.

There are a number of clear limitations in this study. Foremost are the small sample size and the inclusion of only individuals with moderate or severe systemic disease with neurologic presentations. These relate to the demands of patient care, including their life-threatening aspects and caregiver protections. Specifically, the study did not include a control group of patients with COVID-19 of comparable severity but without neurologic manifestations. Nonetheless, the findings are indeed highly provocative and call for further study. Viral RNA was detectable in CSF at low levels in only 1 of 2 assays. Although retesting of low-viral-load samples after freezing and thawing often fails, failure to reproduce viral detection on different platforms definitely adds a high degree of uncertainty to this finding. In addition, the timing of LP varied between 6 and 15 days from estimated disease onset, which may have affected the results.

We found an unusual pattern of marked CSF inflammation measured by the biomarkers neopterin and $\beta_{2} \mathrm{M}$ but without the typical responses of CSF pleocytosis, BBB disruption, or intrathecal IgG production seen in many other CNS infections. Although SARS-CoV-2 RNA was found in the plasma of 2 patients, viral detection in CSF was uncertain, and together, our data do not indicate direct neuroinvasion by SARS-CoV-2 as the underlying mechanism behind the profound CNS immunoactivation seen in this case series.

\section{Study Funding}

Supported by the Swedish State Support for Clinical Research (ALFGBG-717531, ALFGBG-720931, and ALFGBG715986) and SciLifeLab. H.Z. is a Wallenberg Scholar.

\section{Disclosure}

A. Edén, N. Kanberg, J. Gostner, D. Fuchs, L. Hagberg, L.-M. Andersson, M. Lindh, and R.W. Price report no disclosures relevant to the manuscript. H. Zetterberg has served at scientific advisory boards for Denali, Roche Diagnostics, Wave, Samumed, and $\operatorname{CogRx}$; has given lectures in symposia sponsored by Fujirebio, Alzecure, and Biogen; and is a cofounder of Brain Biomarker Solutions in Gothenburg $A B$, which is a part of the GU Ventures Incubator Program. M. Gisslén reports no disclosures relevant to the manuscript. Go to Neurology.org/ $\mathrm{N}$ for full disclosures.

\section{Publication History}

Received by Neurology July 7, 2020. Accepted in final form September 17, 2020.

\section{Appendix Authors}

\begin{tabular}{|c|c|c|}
\hline Name & Location & Contribution \\
\hline $\begin{array}{l}\text { Arvid Edén, } \\
\text { MD, PhD }\end{array}$ & $\begin{array}{l}\text { Department of Infectious } \\
\text { Diseases, Institute of } \\
\text { Biomedicine, Sahlgrenska } \\
\text { Academy, University of } \\
\text { Gothenburg, Sweden }\end{array}$ & $\begin{array}{l}\text { Manuscript writing and } \\
\text { revision, patient } \\
\text { recruitment, data } \\
\text { acquisition, analysis and } \\
\text { interpretation }\end{array}$ \\
\hline $\begin{array}{l}\text { Nelly } \\
\text { Kanberg, MD }\end{array}$ & $\begin{array}{l}\text { Department of Infectious } \\
\text { Diseases, Institute of } \\
\text { Biomedicine, Sahlgrenska } \\
\text { Academy, University of } \\
\text { Gothenburg, Sweden }\end{array}$ & $\begin{array}{l}\text { Manuscript writing and } \\
\text { revision, data } \\
\text { interpretation }\end{array}$ \\
\hline $\begin{array}{l}\text { Johanna } \\
\text { Gostner, } \\
\text { PhD }\end{array}$ & $\begin{array}{l}\text { Institute of Medical } \\
\text { Biochemistry, Medical } \\
\text { University of Innsbruck, } \\
\text { Biocenter, Austria }\end{array}$ & $\begin{array}{l}\text { Diagnostic methods and } \\
\text { analysis }\end{array}$ \\
\hline $\begin{array}{l}\text { Dietmar } \\
\text { Fuchs, PhD }\end{array}$ & $\begin{array}{l}\text { Institute of Biological } \\
\text { Chemistry, Medical } \\
\text { University of Innsbruck, } \\
\text { Biocenter, Austria }\end{array}$ & $\begin{array}{l}\text { Diagnostic methods and } \\
\text { analysis }\end{array}$ \\
\hline $\begin{array}{l}\text { Lars } \\
\text { Hagberg, } \\
\text { MD, PhD }\end{array}$ & $\begin{array}{l}\text { Department of Infectious } \\
\text { Diseases, Institute of } \\
\text { Biomedicine, Sahlgrenska } \\
\text { Academy, University of } \\
\text { Gothenburg, Sweden }\end{array}$ & $\begin{array}{l}\text { Patient recruitment and } \\
\text { manuscript revision }\end{array}$ \\
\hline
\end{tabular}

\begin{tabular}{|c|c|c|}
\hline $\begin{array}{l}\text { Lars-Magnus } \\
\text { Andersson, } \\
\text { MD, PhD }\end{array}$ & $\begin{array}{l}\text { Department of Infectious } \\
\text { Diseases, Institute of } \\
\text { Biomedicine, Sahlgrenska } \\
\text { Academy, University of } \\
\text { Gothenburg, Sweden }\end{array}$ & $\begin{array}{l}\text { Patient recruitment and } \\
\text { manuscript revision }\end{array}$ \\
\hline $\begin{array}{l}\text { Magnus } \\
\text { Lindh, MD, } \\
\text { PhD }\end{array}$ & $\begin{array}{l}\text { Department of Infectious } \\
\text { Diseases, Institute of } \\
\text { Biomedicine, Sahlgrenska } \\
\text { Academy, University of } \\
\text { Gothenburg, Sweden }\end{array}$ & $\begin{array}{l}\text { Data acquisition and } \\
\text { manuscript revision }\end{array}$ \\
\hline $\begin{array}{l}\text { Richard W. } \\
\text { Price, MD }\end{array}$ & $\begin{array}{l}\text { Department of Neurology, } \\
\text { University of California San } \\
\text { Francisco }\end{array}$ & $\begin{array}{l}\text { Data interpretation and } \\
\text { manuscript revision }\end{array}$ \\
\hline $\begin{array}{l}\text { Henrik } \\
\text { Zetterberg, } \\
\text { MD, PhD }\end{array}$ & $\begin{array}{l}\text { Department of Psychiatry } \\
\text { and Neurochemistry, } \\
\text { Institute of Neuroscience \& } \\
\text { Physiology, Sahlgrenska } \\
\text { Academy at the University of } \\
\text { Gothenburg, Mölndal, } \\
\text { Sweden }\end{array}$ & $\begin{array}{l}\text { Study concept and } \\
\text { design, data analysis and } \\
\text { interpretation, } \\
\text { manuscript revision }\end{array}$ \\
\hline $\begin{array}{l}\text { Magnus } \\
\text { Gisslén, MD, } \\
\text { PhD }\end{array}$ & $\begin{array}{l}\text { Department of Infectious } \\
\text { Diseases, Institute of } \\
\text { Biomedicine, Sahlgrenska } \\
\text { Academy, University of } \\
\text { Gothenburg, Sweden }\end{array}$ & $\begin{array}{l}\text { Study concept and } \\
\text { design, patient } \\
\text { recruitment, data } \\
\text { analysis and } \\
\text { interpretation, } \\
\text { manuscript revision, } \\
\text { study supervision }\end{array}$ \\
\hline
\end{tabular}




\section{References}

1. Leonardi M, Padovani A, McArthur JC. Neurological manifestations associated with COVID-19: a review and a call for action. J Neurol 2020;267:1573-1576.

2. Kanberg N, Ashton NJ, Andersson LM, et al. Neurochemical evidence of astrocytic and neuronal injury commonly found in COVID-19. Neurology 2020;95: e1754-e1759.

3. Chaumont H, San-Galli A, Martino F, et al. Mixed central and peripheral nervous system disorders in severe SARS-CoV-2 infection. J Neurol Epub 2020 Jun 12.

4. Logmin K, Karam M, Schichel T, Harmel J, Wojtecki L. Non-epileptic seizures in autonomic dysfunction as the initial symptom of COVID-19. J Neurol 2020;267: 2490-2491.

5. Princiotta Cariddi L, Tabaee Damavandi P, Carimati F, et al. Reversible encephalopathy syndrome (PRES) in a COVID-19 patient. J Neurol Epub 2020 Jun 24.

6. Zachariadis A, Tulbu A, Strambo D, Dumoulin A, Di Virgilio G. Transverse myelitis related to COVID-19 infection. J Neurol Epub 2020 Jun 29.

7. Mao L, Jin H, Wang M, et al. Neurologic manifestations of hospitalized patients with coronavirus disease 2019 in Wuhan, China. JAMA Neurol 2020;77:683-690.

8. Lechien JR, Chiesa-Estomba CM, De Siati DR, et al. Olfactory and gustatory dysfunctions as a clinical presentation of mild-to-moderate forms of the coronavirus disease (COVID-19): a multicenter European study. Eur Arch Otorhinolaryngol 2020;277:2251-2261.

9. Hagberg L, Cinque P, Gisslen M, et al. Cerebrospinal fluid neopterin: an informative biomarker of central nervous system immune activation in HIV-1 infection. AIDS Res Ther 2010;7:15.

10. Fuchs D, Kramer A, Reibnegger G, et al. Neopterin and beta 2-microglobulin as prognostic indices in human immunodeficiency virus type 1 infection. Infection 1991; 19(suppl 2):S98-S102.

11. Yilmaz A, Blennow K, Hagberg L, et al. Neurofilament light chain protein as a marker of neuronal injury: review of its use in HIV-1 infection and reference values for HIVnegative controls. Expert Rev Mol Diagn 2017;17:761-770.
12. Yilmaz A, Mellgren A, Fuchs D, et al. Switching from a regimen containing abacavir/ lamivudine or emtricitabine/tenofovir disoproxil fumarate to emtricitabine/tenofovir alafenamide fumarate does not affect central nervous system HIV-1 infection. Infect Dis (Lond) 2019;51:838-846.

13. Corman VM, Landt O, Kaiser M, et al. Detection of 2019 novel coronavirus (2019. $\mathrm{nCoV}$ ) by real-time RT-PCR. Euro Surveill 2020;25:2000045.

14. Gaetani L, Hoglund K, Parnetti L, et al. A new enzyme-linked immunosorbent assay for neurofilament light in cerebrospinal fluid: analytical validation and clinical evaluation. Alzheimers Res Ther 2018;10:8.

15. Gu J, Gong E, Zhang B, et al. Multiple organ infection and the pathogenesis of SARS. J Exp Med 2005;202:415-424.

16. Arabi YM, Harthi A, Hussein J, et al. Severe neurologic syndrome associated with Middle East respiratory syndrome corona virus (MERS-CoV). Infection 2015;43: 495-501.

17. Netland J, Meyerholz DK, Moore S, Cassell M, Perlman S. Severe acute respiratory syndrome coronavirus infection causes neuronal death in the absence of encephalitis in mice transgenic for human ACE2. J Virol 2008;82:7264-7275.

18. Zhou P, Yang XL, Wang XG, et al. A pneumonia outbreak associated with a new coronavirus of probable bat origin. Nature 2020;579:270-273.

19. Xia H, Lazartigues E. Angiotensin-converting enzyme 2 in the brain: properties and future directions. J Neurochem 2008;107:1482-1494.

20. Moriguchi T, Harii N, Goto J, et al. A first case of meningitis/encephalitis associated with SARS-coronavirus-2. Int J Infect Dis 2020;94:55-58.

21. Paniz-Mondolfi A, Bryce C, Grimes Z, et al. Central nervous system involvement by severe acute respiratory syndrome coronavirus-2 (SARS-CoV-2). J Med Virol 2020; 92:699-702.

22. Frydrych LM, Bian G, O'Lone DE, Ward PA, Delano MJ. Obesity and type 2 diabetes mellitus drive immune dysfunction, infection development, and sepsis mortality. J Leukoc Biol 2018;104:525-534. 


\section{Neurology}

CSF Biomarkers in Patients With COVID-19 and Neurologic Symptoms: A Case Series

Arvid Edén, Nelly Kanberg, Johanna Gostner, et al.

Neurology 2021;96;e294-e300 Published Online before print October 1, 2020

DOI 10.1212/WNL.0000000000010977

This information is current as of October 1,2020

\section{Updated Information \&} Services

References

Citations

Subspecialty Collections

Permissions \& Licensing

Reprints including high resolution figures, can be found at: http://n.neurology.org/content/96/2/e294.full

This article cites 19 articles, 3 of which you can access for free at: http://n.neurology.org/content/96/2/e294.full\#ref-list-1

This article has been cited by 4 HighWire-hosted articles: http://n.neurology.org/content/96/2/e294.full\#\#otherarticles

This article, along with others on similar topics, appears in the following collection(s):

Cerebrospinal Fluid

http://n.neurology.org/cgi/collection/cerebrospinal_fluid COVID-19

http://n.neurology.org/cgi/collection/covid_19

Viral infections

http://n.neurology.org/cgi/collection/viral_infections

Information about reproducing this article in parts (figures,tables) or in its entirety can be found online at:

http://www.neurology.org/about/about_the_journal\#permissions

Information about ordering reprints can be found online:

http://n.neurology.org/subscribers/advertise

Neurology ${ }^{\circledR}$ is the official journal of the American Academy of Neurology. Published continuously since 1951, it is now a weekly with 48 issues per year. Copyright () 2020 American Academy of Neurology. All rights reserved. Print ISSN: 0028-3878. Online ISSN: 1526-632X.

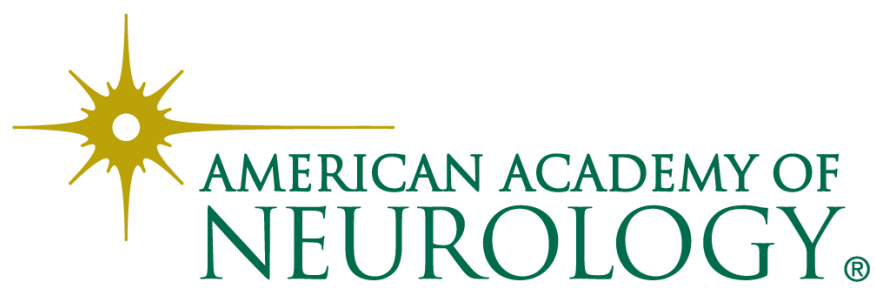

